\title{
Does the Baltic Dry Index predict economic activity in South Africa? A review from 1985 to 2016
}

\begin{tabular}{|c|c|}
\hline \multicolumn{2}{|c|}{$\begin{array}{l}\text { Authors: } \\
\text { Kurt Sartorius }{ }^{1} \\
\text { Benn Sartorius } \\
\text { Dino Zuccollo }\end{array}$} \\
\hline \multicolumn{2}{|c|}{$\begin{array}{l}\text { Affiliations: } \\
{ }^{1} \text { School of Accounting, } \\
\text { University of the } \\
\text { Witwatersrand, South Africa }\end{array}$} \\
\hline \multicolumn{2}{|c|}{$\begin{array}{l}{ }^{2} \text { School of Public Health, } \\
\text { University of KwaZulu-Natal, } \\
\text { South Africa }\end{array}$} \\
\hline \multicolumn{2}{|c|}{$\begin{array}{l}{ }^{3} \text { Westbrooke Alternative } \\
\text { Asset Management, } \\
\text { South Africa }\end{array}$} \\
\hline \multicolumn{2}{|c|}{$\begin{array}{l}\text { Corresponding author: } \\
\text { Kurt Sartorius, } \\
\text { Kurt.Sartorius@wits.ac.za }\end{array}$} \\
\hline \multicolumn{2}{|c|}{$\begin{array}{l}\text { Dates: } \\
\text { Received: } 12 \text { Aug. } 2015 \\
\text { Accepted: } 05 \text { Oct. } 2017 \\
\text { Published: } 05 \text { Apr. } 2018\end{array}$} \\
\hline \multicolumn{2}{|c|}{$\begin{array}{l}\text { How to cite this article: } \\
\text { Sartorius, K., Sartorius, B. \& } \\
\text { Zuccollo, D., 2018, 'Does the } \\
\text { Baltic Dry Index predict } \\
\text { economic activity in South } \\
\text { Africa? A review from } 1985 \\
\text { to } 2016 \text { ', South African } \\
\text { Journal of Economic and } \\
\text { Management Sciences } 21(1) \text {, } \\
\text { a1457. https://doi.org/ } \\
\text { 10.4102/sajems.v21i1.1457 }\end{array}$} \\
\hline \multicolumn{2}{|c|}{$\begin{array}{l}\text { Copyright: } \\
\text { (C) 2018. The Authors } \\
\text { Licensee: AOSIS. This } \\
\text { is licensed under the } \\
\text { Creative Commons } \\
\text { Attribution License. }\end{array}$} \\
\hline \multicolumn{2}{|l|}{ Read online: } \\
\hline 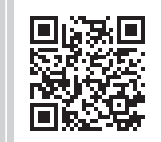 & $\begin{array}{l}\text { Scan this QR } \\
\text { code with your } \\
\text { smart phone or } \\
\text { mobile device } \\
\text { to read online. }\end{array}$ \\
\hline
\end{tabular}

Background: The ability of the Baltic Dry Index to predict economic activity has been evaluated in a number of developed and developing countries.

Aim: Firstly, the article determines the primary factors driving the dynamics of the Baltic Dry Index (BDI) and, secondly, whether the BDI can predict future share price reactions on the Johannesburg Stock Exchange All Share Index (JSE ALSI), South Africa.

Setting: This article investigates the dynamics and predictive properties of the BDI in South Africa between 1985 and 2016.

Methods: The article uses a review of a wide range of published data and two time-series data sets to adopt a mixed methods approach. An inductive contents analysis is used to answer the first research question and a combination of a unit root test, correlation analysis and a Granger causality model is employed to test the second research question.

Results: The results show that the BDI price is primarily driven by four underlying constructs that include the supply and demand for dry bulk shipping, as well as risk, cost and logistics management factors. Secondly, the results indicate a break in the BDI data set in July 2008 that influences a fundamental change in its relationship with the JSE ALSI index. In the pre-break period (1985 to 2008), the BDI is positively correlated with the ALSI $(0.837, \alpha=0.05)$ before sharply diverging in the second period from August 2008 to 2016. In the first period, the BDI showed an optimal lag period of 6 months as a predictor of the ALSI index, but this predictive ability ceases after July 2008. The article makes a two-part contribution. Firstly, it demonstrates that the BDI is a useful predictor of future economic activity in an African developing country. Secondly, the BDI can be incorporated in government and industry sector planning models as a variable to assess future gross domestic product trends.

Conclusion: The study confirms that the BDI is only a reliable indicator of future economic activity when the supply of shipping capacity is well matched with the demand.

\section{Introduction}

Six billion tonnes of sea freight were transported in 2010 by 93000 vessels operating in 25 key shipping routes (Bowden et al. 2010). Approximately $40 \%$ of sea freight consists of dry bulk cargo. ${ }^{1}$ The demand versus supply of dry bulk shipping capacity is tracked by the Baltic Dry Index (BDI) ${ }^{2}$ (Geman \& Smith 2012), which is developed from data obtained from an international panel of ship brokers. The BDI index has changed considerably between 1985 and 2016 (see Figure 1). From its inception in 1985, the BDI demonstrated a steady increase until 2008/2009 and then declined sharply until 2016. Simultaneously, the Johannesburg Stock Exchange All Share Index (JSE ALSI) index increased until 2009/2010; however, it did not track the BDI trend after 2009. The BDI index, based on the demand for dry bulk cargo, has widely been proposed as a proxy for future economic activity (Bakshi, Panayotov \& Skoulakis 2011; Koskinen \& Hilmola 2005).

Given the changes in the trends of these two indexes, the question needs to be posed as to whether the BDI has lost its predictive properties with respect to the ALSI index as a measure of economic activity in South Africa.

The BDI has been used as an economic indicator because it reflects the supply and demand for sea freight that translates into economic activity as reflected by stock market value or growth in gross domestic product (GDP) (Apergis \& Payne 2013; Baltyn 2016). The demand, for instance, for raw commodities like iron ore, is intuitively expected to translate into increasing the GDP 1.Dry bulk cargo is dominated by five main commodities: iron ore, coal, phosphate, grain and alumina (Oomen 2012).

2.The Baltic Dry Index is the successor to the Baltic Freight Index and was brought into operation for the first time on 01 November 1999. 


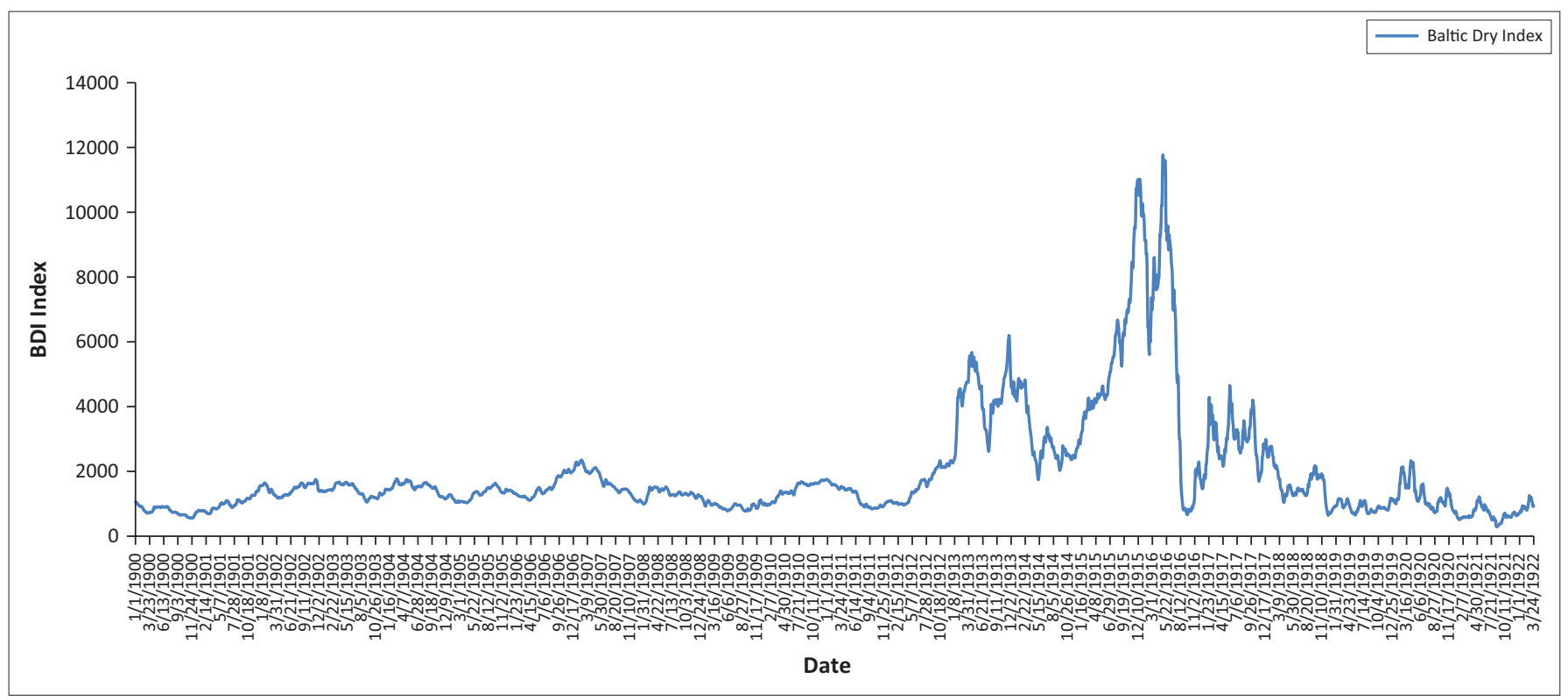

FIGURE 1: Baltic Dry Index price chart, 1985-2016.

(manufacturing output) of the importing country. Changes therefore in the BDI have been assumed to reflect changes in future global economic activity (Alizadeh \& Talley 2011; Blanchflower 2010; Lin \& Sim 2013). The BDI's reliability as a predictor has been enhanced by the proposal that its calculation is devoid of speculative activity (Apergis \& Payne 2013; Koskinen \& Hilmola 2005).

In recent times, the BDI has fallen to an all-time low, reflecting the shrinkage of global GDP because of the cooling of large manufacturing economies like China. Simultaneously, excess dry bulk capacity was created as a result of the over-optimistic commissioning of new vessels during the 2005-2009 peak in dry bulk demand (Hyung-Geun 2011). In South Africa, the importance of dry bulk shipping is significant. In 2010, for instance, 132.7 million tonnes of dry bulk cargo were exported, making up $87 \%$ of the country's total seaward exports for the year (SARS 2013).

The objective of the article is to investigate the dynamics of the BDI, as well as test whether it is a useful predictor of economic activity in a South African context. Two primary problems are investigated. Firstly, what the fundamental dynamics of the BDI and their underlying constructs are and, secondly, whether the BDI predicts share price reactions on the ALSI index of the JSE. The article is essentially an exploratory study and much of the data used to test the first research question are located outside of peer review journals.

The remainder of the article is organised as follows: 'The dynamics of the Baltic Dry Index' section establishes the dynamics of the BDI in order to hypothesise the relationship tested in the second research question. 'Data and method' section outlines the data and method to test the second research question. The 'Findings' section presents the results and the 'Discussion' section concludes the study, as well as makes recommendations for future research.

\section{The dynamics of the Baltic Dry Index}

The overall BDI is disaggregated into four sub-indexes of cargo, namely the Capesize, Panamax, Supramax and Handysize indexes (Geman \& Smith 2012). These sub-indexes reflect the cost of different shipping capacity based on the dead weight in tonnes of cargo. A synthesis of the available literature identifies a number of fundamental factors that drive the BDI price.

\section{Global commodity demand versus shipping supply}

The most fundamental driver of the BDI is the demand for commodities, which is influenced by factors such as global GDP, agricultural production and global energy demand (see Figure 2). The bulk shipping market is seasonal, cyclical and highly volatile (Zeng \& Qu 2014). Because of the nonstationary and non-linear nature of price series and the complexity of influencing factors, it is difficult to analyse the fluctuations in the bulk shipping market. The relationship between GDP and the BDI is explained by assuming raw commodities such as corn, cocoa, coffee, primary metals and coal form the primary ingredients in industries such as the food, manufacturing and energy sectors (Feyrer 2009a, 2009b; Lin \& Sim 2013; McPhail, Du \& Muhammad 2012). Regional indexes like the Asian steel index have a major influence on the BDI (Chou et al. 2015) and individual changes in the larger economies like China that now accounts for $50 \%$ of iron ore imports (Lin \& Sim 2013). The BDI price, for instance, decreased $38 \%$ in 2 months following the decision by the Chinese government to ban new investment in industries such as steel, automobiles and real estate (Hyung-Geun 2011).

The inelasticity of supply has a leverage effect on the BDI and supply inelasticity is a function of long lead times involved in 


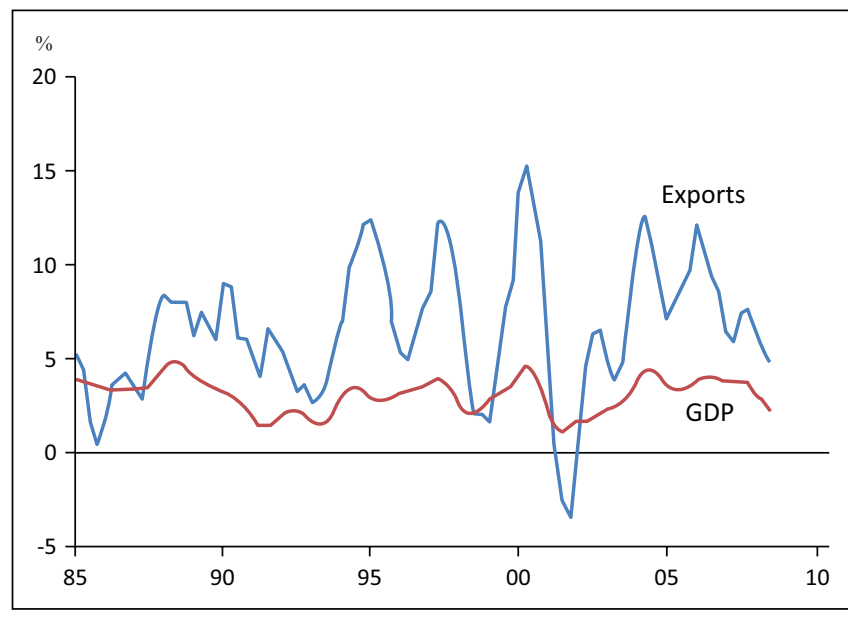

FIGURE 2: Growth rate of global exports plotted against global gross domestic product growth rates.

new ship acquisitions that create a fixed tonne-mile capacity in the short term (Bakshi et al. 2011; Devanney 2010). The ability to change supply capacity is restricted to a 2-3-year period compared to the short-term fluctuations in the demand for cargo carriage (Koskinen \& Hilmola 2005).

\section{Other key Baltic Dry Index price drivers}

Other factors influencing the BDI index, include the lapse between the date the sea freight is contracted for and the date it is required (Laycan period) ${ }^{3}$ and the speculation effects by ship brokers. In addition, older vessels are more expensive to operate and this can also influence their respective hire rates (Alizadeh \& Talley 2011). Bunker prices, closely linked to the price of crude oil, account for $25 \%-33 \%$ of the total cost of operating a transport vessel. The volatility of crude oil prices, in turn, has an influence on the BDI price (Geman \& Smith 2012; Notteboom 2012:\#967).

The existence of bottlenecks (choke points) in global shipping routes has also been identified as a key factor driving the BDI price (Feyrer 2009a, Fu et al. 2010). Nearly half of the world's oil tankers pass through a few narrow sea corridors, which are often subject to piracy, conflict, severe winters and accidents because of high traffic volumes. In recent times, the incidence of piracy in areas like the Somali coastline, the Gulf of Aden and the Suez Canal, has emphasised the risk (cost) associated with these choke points. The risk of piracy is illustrated in 2010 by 500 hostage incidents involving seafarers from more than 18 countries (Bowden et al. 2010). Although difficult to quantify, Bowden estimates that piracy costs the global economy between $\$ 7$ and $\$ 12$ billion per year. For some cargo operators, the increased risk associated with travel in these regions has rendered travel through the Gulf of Aden and the Suez Canal unfeasible. As a result, many cargo operators have decided to re-route via the Cape of Good Hope, which increases the distance by 3500 miles.

3.The laycan period is jargon-specific to the shipping industry (Alizadeh \& Talley 2010) and denotes the period of time between the fixture date and the layday. The fixture date is defined as the date of the conclusion of negotiations between the ship date is defined as the date of the conclusion of negotiations between the ship owner and ship charterer. The product of these negotiations is a signed charte contract. The layday is defined as the contractually stipulated date on which the chartered ship must be delivered to the charterer.
The length and severity of winters along key shipping routes, coupled with seasonal pressures such as reduced global crop yields during winter months, have been identified as further BDI price drivers. These pressures are especially significant along the choke points between January and March each year because of variations in factors like the extent of winter ice in the Baltic Sea (Koslowski \& Loewe 1994).

Other factors influencing the BDI show that freight rates possess a 2.25-4.5-year cyclical tendency; it is supported by the fact that both the recessions of the 1970s and of the 1990s lasted approximately 5 years (Goulielmos \& Psifia 2006). The mean reverting nature of freight rates, discussed above, appears to add credence to this argument (Tvedt 2003). If it is understood that freight rates tend to diverge from their mean value, and then revert to that value at some point in the future, it can be argued that this property is in itself a form of cyclicality, provided that the length of the reversion property is constant. In the case of freight rates, this is proved true through the findings of Goulielmos and Psifia (2006).

\section{The Baltic Dry Index as a predictor of economic activity}

Changes in international shipping freight rates can predict international stock market returns (Alizadeh \& Muradoglu 2014). A number of studies demonstrate that the BDI has a lagged relationship with share prices and commodities (OuYang, Wei \& Zhang 2009). Empirical evidence suggests that this lag period appears to have varied between 1 and 3 months (Bakshi et al. 2011; Oomen 2012; OuYang et al. 2009). One of these studies, for example, that incorporated 23 developed and 25 undeveloped nations, showed a 1-month lag period between the BDI and global stock prices (Oomen 2012). Furthermore, it was found that the BDI was most effective as a predictor for global stock returns in the technology, telecommunications, consumer services and industrial sectors. In terms of the disaggregated BDI index, the Panamax appeared to be the best predictor of economic activity (Bakshi et al. 2011; Oomen 2012). Other research also demonstrated a significant relationship between the BDI and the MSCI Metals and Mining index (Kärrlander \& Lanneström 2010) and that steel and corn prices show the strongest correlation to the BDI growth rate (Mariana 2008).

\section{Data and method}

The article adopts a mixed method approach to test the research questions. An inductive approach, incorporating contents analysis, is employed to test the first research question. The second research question tests whether a causal relationship exists between two sets of time-series data, namely whether the BDI index influences the JSE ALSI index.

\section{The data}

The data for the first research question largely consisted of narrative that was accessed from journal articles, maritime reports, financial and media commentary, as well as internet 
website articles, other reports and reviews. The data for the second question included two financial time-series data sets, namely the BDI and ALSI data indexes. Data from these two indexes were accessed from the Reuters and JSE websites, respectively, for the period May 1985-April 2016.

\section{Research Question 1}

The first research question was to determine the fundamental dynamics of the BDI. Contents analysis incorporating axial and selective coding, was used to analyse the data. Firstly, axial analysis resulted in developing themes influencing the BDI. Selective coding then interrelated some of these and was used to develop an aggregated construct. Because of the multiplicity of factors influencing the dynamics of BDI, a qualitative approach, using an inductive lens, was thought to be the most suitable method (Cresswell \& Plano Clark 2011; Ryan, Scapens \& Theobald 2002).

\section{Research Question 2}

The Zivot-Andrews unit root test was first employed to identify the break in the BDI data (Zivot \& Andrews 2002). This endogenous structural break test incorporates the full sample and uses a range of different dummy variables for each potential break date. The actual break is selected where the $t$-statistic from the Augmented Dickey-Fuller (ADF) test of unit root is at its most negative value. Furthermore, the order of integration was calculated using the ADF unit root test (Dickey \& Fuller 1979) with and without first differencing. The ADF test tests the null hypothesis that a unit root is present in a given time-series. The alternative hypothesis is usually stationarity or trend stationarity. The $\mathrm{ADF}$ test statistic is a negative number and the more negative it is, the stronger the rejection of the hypothesis that there is a unit root at a predefined level of confidence (i.e. usually 95\%). The ADF test can handle more complex models than the standard Dickey-Fuller test, and it is more powerful (Harris 1992).

Correlation analysis for the two periods was then briefly inspected using Spearman's rank correlation (based on Fisher's transformation) between the two data sets. We employed the Johansen-Juselius test to ascertain whether the ALSI and BDI indexes were co-integrated. The JohansenJuselius test is a multivariate generalisation of the ADF test and is an examination of linear combinations of variables for unit roots. The Johansen-Juselius test and estimation approach makes it possible to estimate all co-integrating vectors when there are more than two variables. If there are two variables (as in our case) each with unit roots, there can be at most one co-integrating vector (Johansen \& Juselius 1990).

A Grainger causality model was constructed for both periods (Engle \& Granger 1987) using different lag periods.

We tested for the absence of Granger causality by estimating the following VAR model:
$Y_{t}=a_{0}+a_{1} Y_{t-1}+\ldots . .+a_{p} Y_{t-p}+b_{1} X_{t-1}+\ldots . .+b_{p} X_{t-p}+u_{t} \quad$ [Eqn 1]

$X_{t}=c_{0}+c_{1} X_{t-1}+\ldots . .+c_{p} X_{t-p}+d_{1} Y_{t-1}+\ldots . .+d_{p} Y_{t-p}+v_{t} \quad$ [Eqn 2]

Then, testing $\mathrm{H}_{0}: b_{1}=b_{2}=\ldots . .=b_{p}=0$, against $\mathrm{H}_{\mathrm{A}}$ : 'Not $\mathrm{H}_{0}{ }^{\prime}$, is a test that $X$ does not Granger-cause $Y$. Similarly, testing $\mathrm{H}_{0}$ : $d_{1}=d_{2}=\ldots . .=d_{p}=0$, against $\mathrm{H}_{\mathrm{A}}:{ }^{\prime} \mathrm{Not} \mathrm{H}_{0}{ }^{\prime}$, is a test that $Y$ does not Granger-cause $X$.

The properties of the model were tested at a range of lag periods (1-9 months). The optimum lag period was confirmed by the Akaike information criterion (AIC) (Akaike 1977). Finally, a range of diagnostics to ensure the validity of the Grainger causality model included the Wald test for Granger non-causality, where rejection of the null hypothesis implies causality. Furthermore, we employed the vector errorcorrection model (VECM) (Johansen 1988) to estimate the adjusted parameters (including an alpha to obtain the shortrun adjustment parameters) for both ALSI and BDI to ascertain which one potentially responded more to shock or disequilibria.

Short- and long-run equilibria between ALSI and BDI were assessed using the VECM (Engle \& Granger 1987) (second stage) with following specification:

$d(\mathrm{ALSI})=b 2 * d(\mathrm{BDI})+b 3 * \varepsilon_{t-1}+V$

[Eqn 3]

where $d(\mathrm{ALSI})$ is the first difference of ALSI , $d$ (BDI) is the first difference of BDI , $\varepsilon_{t-1}$ is the one-period lag of residual obtained from the OLS estimation**, $b 2$ is the short-run equilibrium coefficient and $b 3$ is the coefficient for the oneperiod lag-correction term or residual from the first stage model and relates to the restoration of the system back to equilibrium, that is, long-run equilibrium and $V$ is the error term.

**Ordinary least squares (OLS)-level model (first stage):

$\mathrm{ALSI}_{t}=b 0+b 1 * \mathrm{BDI}_{t}+\varepsilon_{t}$

[Eqn 4]

where ALSI is the All Share Index value, BDI is the Baltic Dry Index value, $t$ is the month, $\varepsilon_{t}$ is the error term (residual difference between observed and fitted values), $b 0$ is the intercept and $b 1$ is the slope coefficient for unlagged BDI versus ALSI.

\section{Findings Research Question 1}

Axial coding of the contents documents demonstrates a number of key themes that were demonstrated in all the literature (see Figure 3). These themes include the demand for shipping, the fixed nature of shipping supply, the Laycan period, vessel size and age, bunker prices, the effect of piracy and global winters. Other factors include the number of shipping routes (25), the number of vessels, port costs, 


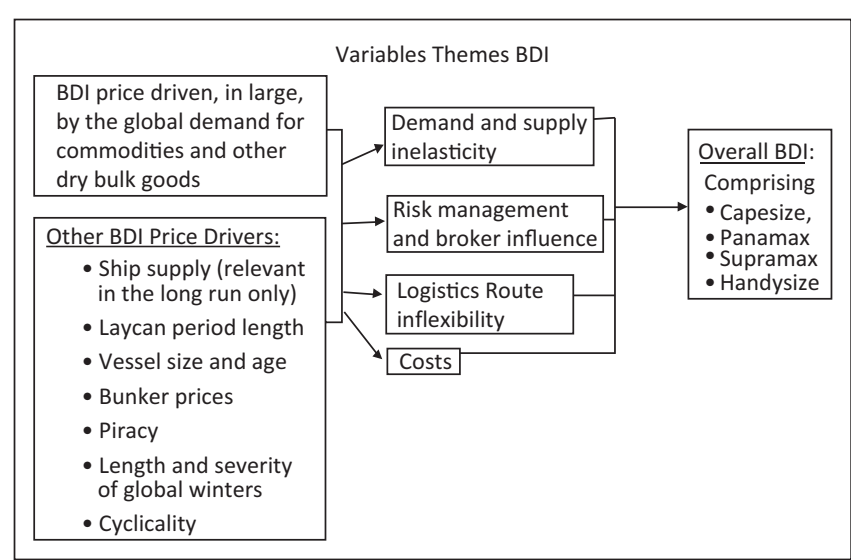

FIGURE 3: Factors influencing the Baltic Dry Index and its resultant impact on economic activity.

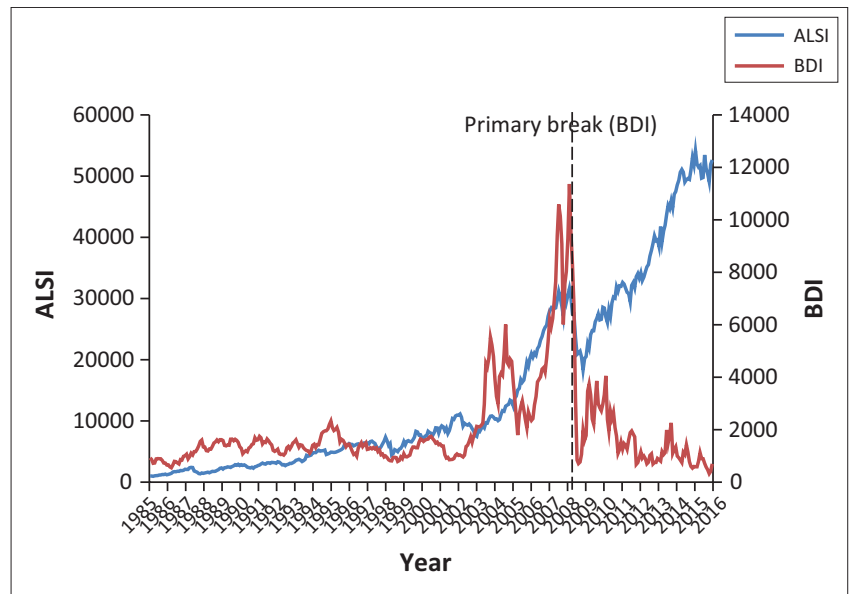

FIGURE 4: Baltic Dry Index and All Share Index trends (including identified break).

administration and a cyclical component. Selective coding was used to aggregate the axial codes into four major constructs. This included a demand and supply function that largely incorporated global demand for shipping versus shipping capacity.

The other axial codes included a risk management and speculative component (Laycan period, broker speculation, piracy, climatic conditions and a cyclical component), a logistics construct (number of vessels, number of routes, choke points and climatic conditions) and a cost management aspect (cost and maintenance of vessels, bunker oil prices and docking fees). The BDI, which is disaggregated into four major components (see Figure 3), is thus influenced by a complex set of variables that make it difficult to model empirically.

\section{Research Question 2}

The Zivot-Andrews unit root test was first employed to identify the break in the BDI data (Zivot \& Andrews 2002) to effectively create two data sets. Correlation analysis was used to illustrate the association in both periods, before confirming the first data sets were co-integrated using the Johansen-Juselius test for co-integration. An optimal Granger causality model was then developed and tested. Lastly, a
VECM was developed to assess the magnitude of the coefficients and also ascertain which variable was leading and which was lagging.

\section{Descriptive analysis and unit root analysis}

Figure 4 depicts the relationship between monthly BDI price and JSE ALSI price movements for the period 1985-April 2016. An application of the Zivot-Andrews test indicates a structural break in the BDI series, occurred in July 2008 (minimum $t$-statistic was -5.641 : critical values: $1 \%$ : $-5.57,5 \%$ : $-5.08,10 \%$ : -4.82). From 1985 to July 2008, the BDI had a steady upward trend that appeared consistent with the JSE ALSI trend. After July 2008, the BDI declines markedly, while the ALSI index maintains its upward trend to 2016.

The MacKinnon approximate $p$-values from the ADF test for unit without differencing for both ALSI and BDI with a trend component were 0.852 and 0.218 , respectively (see Table 1 ). As a trend in levels becomes a constant in first differences, no trend was included for the first differenced Dickey-Fuller tests but drift assumed. Both null hypotheses are rejected for the differenced series ( $p<0.01$ for both).

As both raw series are not stationary but the first difference is stationary and invertible as suggested by the ADF test results, this suggests that both times series are (1).

\section{Correlation analysis and co-integration}

In the first period up to June 2008, the correlation $=0.836$ on 138 observations (95\% confidence interval (CI): 0.797-0.868), as illustrated in Figure 5. It is clear in this period that both the BDI and the ALSI have increased, showing that they were positively correlated (red line) with a linear trend between the two indexes (green line) to reflect both a higher BDI price as well as increased share prices.

In the second period (July 2008-April 2016), we observed a negative correlation of -0.677 on ( $95 \%$ CI: 0.774 to -0.550 ) clearly illustrating the downward turn in the BDI index, while the ALSI continued to increase.

Prior to the break in 2008, the first hypothesis for the Johansen-Juselius test, $r=0$, which tests for the presence of co-integration, had a test statistic of 23.21 (which exceeded the 17.95 critical cut-off at $5 \%$ level and was close to the $1 \%$ critical value of 23.52), that is, $p<0.05$, and thus suggested that we have evidence to reject the null hypothesis of no co-integration, that is, the two series (ALSI and BDI) were

TABLE 1: Augmented Dickey-Fuller test results for level and first difference for both All Share Index and Baltic Dry Index time-series, 1985-2016.

\begin{tabular}{|c|c|c|c|}
\hline Variable & ADF test (level) & ADF test (first difference) & $\begin{array}{l}\text { Integration } \\
\text { order }\end{array}$ \\
\hline ALSI & $\begin{array}{l}\text { Test statistic }=-1.349, p \text {-value } \\
=0.852 \text {, } \\
\text { that is, non-stationary }\end{array}$ & $\begin{array}{l}\text { Test statistic }=-6.783, p \text {-value } \\
<0.01 \text {, } \\
\text { that is, stationary }\end{array}$ & $I(1)$ \\
\hline BDI & $\begin{array}{l}\text { Test statistic }=-2.850, p \text {-value } \\
=0.218 \text {, } \\
\text { that is, non-stationary }\end{array}$ & $\begin{array}{l}\text { Test statistic }=-8.006, p \text {-value } \\
<0.01 \text {, } \\
\text { that is, stationary }\end{array}$ & $I(1)$ \\
\hline
\end{tabular}

ALSI, All Share Index; BDI, Baltic Dry Index. 


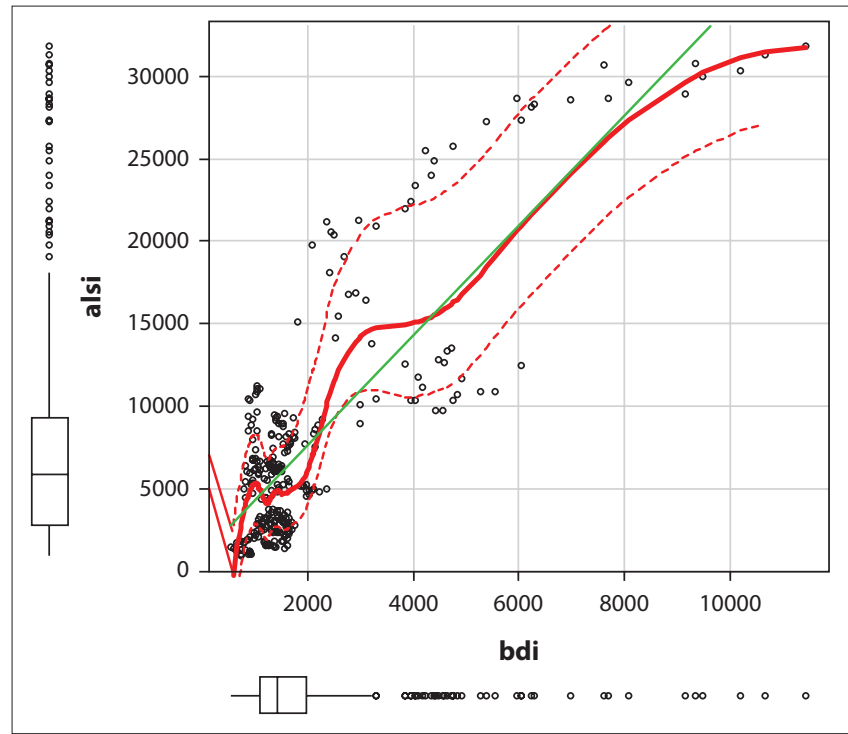

FIGURE 5: Scatterplot with fit lines and marginal boxplots showing correlation between All Share Index and Baltic Dry Index pre-break, May 1985-June 2008.

TABLE 2: Grander causality test results for All Share Index versus Baltic Dry Index for the full period and pre- and post-break, 1985-2016.

\begin{tabular}{lccc}
\hline Period & Lag order & $\begin{array}{c}\text { Granger causality } \\
\text { test statistic }\end{array}$ & $p$ \\
\hline Full & 6 & 1.0416 & 0.398 \\
Pre-break & 6 & 3.7248 & $0.001 \dagger$ \\
Post-break & 6 & 1.3451 & 0.246 \\
\hline
\end{tabular}

$\dagger, \alpha \leq 1 \%$.

co-integrated prior to the break. We observed a similar finding post the identified structural break in 2008, with a test statistic of 23.21 for $r=0$ (which exceeded the 23.52 critical cut-off at $1 \%$ level), that is, $p<0.01$, and thus suggested that we have strong evidence to reject the null hypothesis of no co-integration, that is, the two series (ALSI and BDI) were also co-integrated post-break.

\section{Granger causality}

The results of the Granger causality test pre-break (January 1985-June 2008) indicated a $p$-value of 0.001), and thus we rejected the null hypothesis of no Granger causality (Table 2). This indicates that Model 2 (ALSI Lags(ALSI, 1:6), i.e. without BDI as a causal covariate) is too restrictive as compared with Model 1 (Model 1: ALSI Lags(ALSI, 1:6) + Lags(BDI, 1:6), i.e. with BDI included as a covariate). This relationship was no longer significant post-break $(p=0.246)$, that is, for the post-break period, we observed an inverse and non-linear relationship between BDI and ALSI.

\section{Vector error-correction model}

The adjusted parameter estimates for ALSI and BDI from the VECM model suggest that ALSI may respond more if there is change or shock in the system compared to BDI [alpha coefficient $(\alpha)=0.0032(p=0.017)$ and $\alpha=0.0016(p=$ $0.025)]$, respectively. However, the overlap of the confidence intervals (CIs) suggests that these alphas are not significantly different $(\alpha 95 \%$ CIs of $0.0006-0.0057$ and $0.0002-0.003$, respectively).
TABLE 3: Vector error-correction model results for the pre-break period, May 1985-June 2008.

\begin{tabular}{lcccc}
\hline Term (on log scale) & Coefficient & Std. error & Statistic & $\boldsymbol{p}$ \\
\hline $\begin{array}{l}\text { Co-integration } \\
\text { equation }\end{array}$ & 0.598 & 0.070 & 8.527 & $<0.001$ \\
ALSI-(Intercept) & 16.37 & 15.34 & 1.067 & 0.287 \\
ALSI-L( $\left(e^{\wedge} t-1\right)$ & 0.99 & 0.03 & 31.89 & $<0.001$ \\
BDI-(Intercept) & 27.38 & 25.65 & 1.067 & 0.287 \\
BDI-L( $\left.e^{\wedge} t-1\right)$ & -0.009 & 0.05 & -0.17 & 0.862 \\
\hline
\end{tabular}

ALSI, All Share Index; BDI, Baltic Dry Index; Std. error, standard error.

TABLE 4: Results of error-correction model using first difference for All Share Index and Baltic Dry Index for estimation of short- and long-run disequilibrium correction.

\begin{tabular}{lcccc}
\hline Variable & Coefficient & Std. error & $t$-Statistic & $p$ \\
\hline Intercept & 81.32 & 29.06 & 2.80 & 0.006 \\
$D(\mathrm{BDI})(\mathrm{b} 3)$ & 0.55 & 0.07 & 7.77 & $<0.001$ \\
$U_{t-1}(\mathrm{~b} 4)$ & 0.016 & 0.007 & 2.18 & 0.030 \\
$R$-squared & - & - & - & 0.219 \\
Adjusted & - & - & - & 0.213 \\
$R$-squared & - & - & 34.44 & $<0.001$ \\
\hline -statistic & - & - & & \\
\hline
\end{tabular}

ALSI, All Share Index; BDI, Baltic Dry Index; Std. error, standard error; $D$, first difference. First difference was also applied to the dependent variable, namely, ALSI.

\section{Leading and lagging variable}

The coefficient on the error-correction term $\left(e^{\wedge} t-1\right)$ is highly significant for ALSI $(p<0.001)$, suggesting that changes in BDI do affect ALSI (Table 3). Furthermore, the errorcorrection coefficient in the BDI equation is not statistically significant $(p=0.862)$, suggesting that changes in ALSI do not influence BDI.

The coefficients of $d$ (BDI) and one-period lag error-correction term $\left(U_{t-1}\right)$ represent the equilibrium position in the short and long runs, respectively (Table 4 ). The coefficient $b 3$ is positive, indicating that there is positive relationship between $d$ (ALSI) and $d(\mathrm{BDI})$ as expected based on the previous results. A one unit change in difference BDI series results in a 0.55 shift in the differenced value of the ALSI $(p<0.0001)$.

\section{Short-run equilibrium}

The estimated value of $b 3$ (short-run coefficient which represents the short-run equilibrium) is 0.55 and is statistically highly significant (Table 4). In brief, it indicates the rate at which the previous period disequilibrium of the system is being corrected. Thus, the value of 0.55 suggests that the system corrects its previous period disequilibrium at a speed of $55.0 \%$ between variables ALSI and BDI.

\section{Long-run equilibrium}

The coefficient of $b 4$ was significant and is significant at $5 \%$ level (Table 4). This suggests that the system corrects its previous period disequilibrium at a speed of $1.6 \%$ monthly, that is, monthly correction for reaching long-run equilibrium steady state.

\section{Discussion}

This section discusses the dynamics of the BDI and its underlying constructs before examining the predictive properties of this index in a South African context. 


\section{The dynamics of the Baltic Dry Index}

The findings, based on an inductive review of a wide range of data, suggest that four key constructs influenced the BDI price between 1985 and 2009. The validity of the themes (axial codes) in our results are underpinned by a wide range of literature that suggests that the BDI is influenced by the inelasticity of shipping supply volume (Koskinen \& Hilmola 2005), global commodity demand (Oomen 2012), countrylevel effects like the 'Chinese Factor' (Hyung-Geun 2011) and the contract details and speculation effect (Laycan period) between ship owners and charterers (Alizadeh \& Talley 2011). Other factors included costs such as bunker prices, the maintenance of vessels and other freight costs (Notteboom \& Vernimmen 2009), and choke points in global shipping routes because of issues like weather (the Baltic Winter) and the effects of piracy (Fu et al. 2010). Aggregating these themes, this article proposes that they are better understood in terms of four basic constructs, namely supply and demand of dry bulk shipping, and a combination of risk, cost and logistics management factors.

The BDI is currently at an all-time low. Recent speculation indicates that the dynamics of the BDI have changed because of an oversupply of shipping capacity. Increased demand for dry bulk cargo is therefore unlikely to be reflected in an increase in the BDI in the short term because of this excess capacity, which was commissioned when the BDI was at a peak in 2009/2010. A question therefore exists as to whether the historic dynamics of the BDI will resume over the longer term as supply and capacity are eventually matched.

\section{The Baltic Dry Index as a predictor of the All Share index}

\section{Periods of significant convergence or divergence}

The results clearly demonstrate a fundamental difference between 1985-July 2008 compared to the ensuing divergence until 2016. In the first period, the hypothesised predictive power of the BDI appears to hold true and the relationship between the BDI and the ALSI exhibits a period of significant convergence. This positive association is supported by other studies that show co-integration, high levels of correlation and significant causality between the BDI and share price indexes in both developed and developing countries (Apergis \& Payne 2013; Bakshi et al. 2011; Baltyn 2016; Lin \& Sim 2013; Oomen 2012).

The post-break relationship between the BDI and the ALSI in the period 2008-2016 illustrates negative correlation (-0.677), namely that an increase in the ALSI index was associated with a decrease in the BDI. Although this negative correlation is significant $(\alpha=0.05)$, it represents a medium-term anomaly that is caused by having more ships than cargoes and the recognition that the BDI index has both supply and demand components (Worstall 2015). In this period, the supply of shipping capacity doubled, while global GDP and exports cooled. In the period 2009-2016, South Africa's dry bulk trade growth of iron ore, coal, agricultural commodities and steel actually increased. This would explain why the ALSI index increased at the same time as the BDI decreased. It could be expected, however, that a normal positive relationship would re-assert itself in the future when shipping capacity for dry bulk is again more evenly matched with demand.

\section{Optimal lag period}

The optimum pre-break BDI lag period, which maximises the significance of Granger causality between the BDI and ALSI, was 6 months. This lag is considerably longer than the findings of Bakshi et al. (2011), as well as those of Oomen (2012), who both conclude a lag period of between 1 and 3 months, maximise the correlation of these two data sets. These studies were based on a relationship between the BDI and share price indexes in both developed and developing countries. The longer lag period in our results needs to be examined further and a question remains as to how a commodities-based economy like South Africa's influences this lag period. In this regard, a developing country like South Africa has primarily relied on the export of minerals. Conversely, developed countries import the same commodities as ingredients in a range of industry sectors. According to our results, a possible explanation for the difference in the lag period is that different economic sectors translate a BDI-related transaction into shareholder wealth in different time frames.

\section{Limitations}

The exploratory nature of the article is acknowledged and our findings should be subjected to further rigorous empirical investigation to generalise our conclusions. Firstly, the causal relationship between the BDI and the ALSI for the period 1985-2008 should be disaggregated to test the relationship of the BDI with specific industry sectors on the JSE rather than the aggregated ALSI index. The data exist therefore to more acutely test a range of relationships between components of the BDI and different industry sectors in South Africa, as well as other developing countries, in order to understand the role of the BDI when (presumably) the oversupply of shipping capacity corrects itself over time.

In the shorter term, the dynamics of the BDI need to be reassessed in order to understand the implications of the relationship between global economic activity and the BDI. The data exist, for example, to determine freight volumes as a proxy, while the BDI remains understated because of spare capacity.

\section{Conclusion}

This article examined two key questions that included evaluating the dynamics of the BDI and whether the BDI was a predictor of economic activity. Firstly, the BDI price is an economic indicator that is influenced by four primary constructs that include supply and demand, as well as risk, cost and logistics management components. These constructs are underpinned by the global demand for raw commodities 
versus supply of shipping capacity, the Laycan period, broker speculation, piracy, a cyclical component (risks) bunker prices, maintenance (costs) and choke points, shipping routes, the volume of shipping and climatic conditions (logistics).

Secondly, the results indicate that for the BDI to act as a proxy for future economic growth in South Africa, the supply of shipping capacity must be matched with the demand for sea freight. In the first period, namely, 1985-2008, both shipping capacity and demand had a steady upward trend. The results show significant positive correlation between the two variables and the Grainger causality model demonstrated that changes in the BDI influence changes in the ALSI in the pre-break period. The BDI in this period showed a positive lagged (6 months) causal relationship with the ALSI. In the period 2009-2016, however, global shipping capacity doubled while demand cooled, precipitating a sharp drop in the BDI. At the same time, however, the ALSI index increased, thus reflecting negative correlation with the BDI. Although the data sets are negatively correlated in the second period, it is assumed to be a short-term anomaly that will correct itself as demand catches up with supply.

Future research could further investigate the optimal lag period between the BDI and ALSI sectors. Our article acknowledges that the Granger causality model was developed purely to show a causal relationship between two aggregated time-series data sets that should ideally be disaggregated into their components for sharper comparison. In this regard, our intention was to adopt a broad exploratory approach, and thus, we caution against generalising these results. The current divergence, illustrated between the BDI and ALSI between 2008 and 2016, requires a full investigation in future research.

\section{Acknowledgements}

This study was funded by the National Research Foundation.

\section{Competing interests}

The authors declare that they have no financial or personal relationship(s) that may have inappropriately influenced them in writing this article.

\section{Authors' contributions}

K.S. conceptualised and revised the problem. B.S. was the statistician. D.Z. conceptualised the original problem. All authors contributed to developing, reviewing and revising the article.

\section{References}

Akaike, H., 1976, 'Canonical correlation analysis of time series and the use of an information criterion', Mathematics in Science and Engineering 126, 27-96.

Alizadeh, A.H. \& Muradoglu, G., 2014, 'Stock market efficiency and international shipping-market information', Journal of International Financial Markets, Institutions and Money 33, 445-461. https://doi.org/10.1016/j.intfin.2014. 10.002
Alizadeh, A.H. \& Talley, W.K., 2011, 'Microeconomic determinants of dry bulk shipping freight rates and contract times', Transportation 38, 561-579. https://doi.org/ 10.1007/s11116-010-9308-7

Apergis, N. \& Payne, J.E., 2013, 'New evidence on the information and predictive content of the Baltic Dry Index', International Journal of Financial Studies 1, 62-80.

Bakshi, G., Panayotov, G. \& Skoulakis, G., 2011, 'The Baltic Dry Index as a predictor of global stock returns, commodity returns, and global economic activity', in AFA 2012 Chicago Meetings Paper, January 26, SSRN, pp 1-52, viewed from https:// ssrn.com/abstract=1787757 or https://doi.org/10.2139/ssrn.1787757

Baltyn, P., 2016, 'Baltic Dry Index as economic leading indicator in the United States', in Managing innovation and diversity in knowledge society through turbulent time: Proceedings of the MakeLearn and TIIM Joint International Conference 2016, ToKnowPress, Timisoara, Romania, May 25-27, pp. 205-211.

Blanchflower, D., 2010, 'The Baltic Dry signals trouble ahead', New Statesman 139, 17.

Bowden, A., Hurlburt, K., Aloyo, E., Marts, C. \& Lee, A., 2010, The economic costs of maritime piracy, One Earth Future Foundation, Broomfield, $\mathrm{CO}$

Chou, M.-T., Su, Y.-L., Chou, T.-Y. \& Liang, H.-U., 2015, 'An analysis of the relationship between Asian Steel Index and the Baltic Capsize Index', Modern Economy 6, 207. https://doi.org/10.4236/me.2015.62018

Cresswell, J.W. \& Plano Clark, V.L., 2011, Designing and conducting mixed method research, 2 nd edn., Sage, Thousand Oaks, CA.

Devanney, J., 2010, 'The impact of bunker price on VLCC spot rates', in Proceedings of the 3rd International Symposium on Ship Operations, Management and Economics, SNAME Greek Section, Athens, Greece, October 7-8, pp. 1-9.

Dickey, D.A. \& Fuller, W.A., 1979, 'Distribution of the estimators for autoregressive time series with a unit root', Journal of the American Statistical Association 74, 427-431.

Engle, R.F. \& Granger, C.W., 1987, 'Co-integration and error correction: Representation, estimation, and testing', Econometrica: Journal of the Econometric Society 55 , 251-276. https://doi.org/10.2307/1913236

Feyrer, J., 2009a, Distance, trade, and income - The 1967 to 1975 closing of the suez canal as a natural experiment, NBER Working Paper No. 15557, Issued in December 2009, National Bureau of Economic Research. Cambridge, MA.

Feyrer, J., 2009b, Trade and income - Exploiting time series in geography, National Bureau of Economic Research, Cambridge, MA.

Fu, X., Ng, A.K. \& Lau, Y.-Y., 2010, 'The impacts of maritime piracy on global economic development: The case of Somalia', Maritime Policy \& Management 37, 677-697. https://doi.org/10.1080/03088839.2010.524736

Geman, H. \& Smith, W.O., 2012, 'Shipping markets and freight rates: An analysis of the Baltic Dry Index', The Journal of Alternative Investments 15, 98-109.

Goulielmos, A.M. \& Psifia, M., 2006, 'Shipping finance: Time to follow a new track?', Maritime Policy \& Management 33, 301-320. https://doi.org/10.1080/ 03088830600783301

Harris, R.I., 1992, 'Testing for unit roots using the augmented Dickey-Fuller test: Some issues relating to the size, power and the lag structure of the test', Economics Letters 38, 381-386. https://doi.org/10.1016/0165-1765(92)90022-Q

Hyung-Geun, K., 2011, 'Study about how the Chinese economic status affects to the tramper economy', East China Economic Management 4, 116-123.

Johansen, S., 1988, 'Statistical analysis of cointegration vectors', Journal of Economic Dynamics and Control 12, 231-254. https://doi.org/10.1016/0165-1889(88) 90041-3

Johansen, S. \& Juselius, K., 1990, 'Maximum likelihood estimation and inference on cointegration - With applications to the demand for money', Oxford Bulletin of Economics and Statistics 52, 169-210. https://doi.org/10.1111/j.1468-0084.1990. mp52002003.x

Kärrlander, E. \& Lanneström, G., 2010, 'Base metals, a base for stock prices', Bachelor thesis, Lund University, Scania, Sweden.

Koskinen, M.-M. \& Hilmola, O.-P., 2005, 'Investment cycles in the newbuilding market of ice-strengthened oil tankers', Maritime Economics \& Logistics 7, 173-188. $\mathrm{https} / / /$ doi.org/10.1057/palgrave.mel.9100128

Koslowski, G. \& Loewe, P., 1994, 'The western Baltic sea ice season in terms of a massrelated severity index: 1879-1992', Tellus A 46, 66-74. https://doi.org/10.3402/ tellusa.v46i1.15433

Lin, F. \& Sim, N.C., 2013, 'Trade, income and the Baltic Dry Index', European Economic Review 59, 1-18. https://doi.org/10.1016/j.euroecorev.2012.12.004

Mariana, E., 2008, 'A non-linear dynamic model of raw materials in dry bulk shipping market', PhD thesis, 成功大學國際經營管理研究所碩士班學位論文, pp. $1-50$

Mcphail, L.L., Du, X. \& Muhammad, A., 2012, 'Disentangling corn price volatility: The role of global demand, speculation, and energy', Journal of Agricultural and Applied Economics 44, 401-410.

Notteboom, T., 2012, Container shipping, Wiley-Blackwell, Chichester.

Notteboom, T.E. \& Vernimmen, B., 2009, 'The effect of high fuel costs on liner service configuration in container shipping', Journal of Transport Geography 17, 325-337. https://doi.org/10.1016/j.jtrangeo.2008.05.003

Oomen, J., 2012, 'The Baltic Dry Index: A predictor of stock market returns', Master's thesis, Tilburg University, Tilburg.

Ouyang, H., Wei, Z. \& Zhang, H., 2009, Predictive signals and asset allocation, SSRN eLibrary.

Ryan, B., Scapens, R. \& Theobald, M., 2002, Research method and methodology in finance and accounting, Thomson, London. 
SARS, 2013, South African Trade Statistics for April 2013, viewed n.d., from http://www. sars.gov.za/ClientSegments/Customs-Excise/Trade-Statistics/Pages/default.aspx

Tvedt, J., 2003, 'A new perspective on price dynamics of the dry bulk market', Maritime Policy \& Management 30, 221-230. https://doi.org/10.1080/0308883032000133413

Worstall, T., 2015, 'Why you shouldn't worry about the Baltic Dry Index hitting a 29 year low', Economics and Finance. Forbes, February, p. 1.
Zeng, Q. \& Qu, C., 2014, 'An approach for Baltic Dry Index analysis based on empirical mode decomposition', Maritime Policy \& Management 41, 224-240. https://doi. org/10.1080/03088839.2013.839512

Zivot, E. \& Andrews, D.W.K., 2002, 'Further evidence on the great crash, the oil-price shock, and the unit-root hypothesis', Journal of Business \& Economic Statistics 20 25-44. https://doi.org/10.1198/073500102753410372 